\title{
Thymus-Dependent Lymphocytes in Human Bone Marrow
}

\author{
Robert Peter Gale, Gerhard Opelz, M. Kruchi, and David W. Golde \\ From the Departments of Medicine, Surgery, and Microbiology and \\ Immunology, School of Medicine, University of California, \\ Los Angeles, California 90024
}

A B S T R A C T Human bone marrow is known to contain significant numbers of bursa-dependent lymphocytes. The presence of thymus-dependent $(T)$ cells is controversial. Bone marrow cells obtained from healthy volunteers was fractionated by density centrifugation. A lymphocyte-enriched subpopulation was shown to be reactive to alloantigens in mixed lymphocyte culture and to contain substantial numbers of $\mathrm{T}$ lymphocytes. The $T$ lymphocytes were detected by cell surface markers (rosette formation with sheep $\mathrm{RBC}$ ) and by response to the mitogens phytohemagglutinin and concanavalin A. Bone marrow $T$ cells exhibited functional characteristics quantitatively different from peripheral blood $T$ cells, suggesting that they may represent a particular subpopulation of $\mathrm{T}$ cells. The lymphocyte-enriched fraction additionally contained committed granulopoietic stem cells capable of colony formation in semisolid gel. The presence of $\mathrm{T}$ cells in human bone marrow is consistent with findings in other mammals and may explain the high incidence of graft versus host disease in bone marrow transplant recipients.

\section{INTRODUCTION}

Peripheral blood lymphocytes can be divided into two major subpopulations: thymus-dependent $(T)^{1}$ cells and bursa-dependent (B) cells. In most species, bone marrow lymphocytes are predominantly of the B-cell type (1-5). Recent studies using mice indicate that $\mathrm{T}$ cells and $\mathrm{T}$-cell progenitors are also present in the bone marrow (6-11). The situation in man is unclear.

Dr. Gale is the Bogert Fellow of the Leukemia Society of America.

Received for publication 16 April 1975 and in revised form 17 July 1975.

${ }^{1}$ Abbreviations used in this paper: B, bursa-dependent; B-RFC, B-rosette-forming cells; CFU-C, colony-forming cells ; ConA, concanavalin A; HBSS, Hanks' balanced salt solution; PBS, phosphate-buffered saline; PHA, phytohemagglutinin; SRBC, sheep red blood cells; $T$, thymusdependent; T-RFC, T-rosette-forming cells.
Several studies have reported the absence of cells with $T$ characteristics $(4,5,12)$ while other investigators found phytohemagglutinin (PHA) and alloantigen responsive cells in human marrow $(13,14)$.

In addition to lymphoid cells, bone marrow contains committed granulopoietic stem cells (CFU-C) capable of colony formation in semisolid gel. These cells and their progenitor, the pluripotent hematopoietic stem cell, are morphologically similar to lymphocytes (15, 16). In murine systems, hematopoietic stem cells have been separated from lymphocytes by density centrifugation $(7,17)$.

In order to determine if $\mathrm{T}$ lymphocytes are present in human marrow, we obtained multiple small aspirates from normal volunteers. Mononuclear cells were isolated by density centrifugation and studied for $\mathrm{T}$ - and B-lymphocyte cell surface marker and functional characteristics and for colony-forming capacity in agar. The results indicate that substantial numbers of lymphocytes with $\mathrm{T}$-cell characteristics are present in normal human bone marrow. Bone marrow $T$ cells differ from peripheral blood $\mathrm{T}$ cells in their response to mitogens and alloantigens.

\section{METHODS}

Bone marrow cells. Informed consent was obtained from normal volunteers, ages 20 to 35 yr. Bone marrow was obtained from the posterior iliac crest by a sterile technique. 1-ml aliquots were carefully aspirated from separate sites along the posterior iliac crest and mixed with $500 \mathrm{U}$ of preservative-free heparin. $60-\mathrm{ml}$ samples of heparinized peripheral venous blood were obtained from marrow donors at the time of marrow aspiration.

Fractionation of bone marrow. The heparinized bone marrow was centrifuged $\left(2,000 \mathrm{~g}\right.$ at $\left.24^{\circ} \mathrm{C}\right)$ for $2 \mathrm{~min}$ and the leukocyte-rich supernate was recovered. Antisera to A and/or B substance (Ortho Diagnostics, Raritan, N. J.) were added, as determined by the blood type of the donor, and the suspension was mixed gently for $5 \mathrm{~min}$ at $24^{\circ} \mathrm{C}$ to agglutinate the red cells. The suspension was centrifuged at $1,000 \mathrm{~g}$ at $24^{\circ} \mathrm{C}$ for $5 \mathrm{~s}$ and the nucleated cells recovered and carefully layered over a Ficoll-Hypaque gradient prepared according to the method of Boyum (18). The gradient tube was then centrifuged at $1,000 \mathrm{~g}$ at $24^{\circ} \mathrm{C}$ for 2 
min. The light cell fraction (I) was collected by aspirating the interface cells. After a preliminary centrifugation at $3,000 \mathrm{~g}$ at $24^{\circ} \mathrm{C}$ for $1 \mathrm{~min}$, the supernate was discarded and the cells resuspended in McCoy's medium (Grand Island Biological Co., Santa Clara, Calif.) and centrifuged at $1,000 \mathrm{~g}$ at $24^{\circ} \mathrm{C}$ for $7 \mathrm{~s}$. The supernate containing the light cells was aspirated and saved, and the pellet was resuspended with McCoy's and recentrifuged. This process was repeated five times, and the supernates were pooled, washed once in TC-199 medium (Grand Island Biological Co.) and resuspended to the desired concentration.

To prepare the heavy cell fraction (II), the pellet from the Ficoll-Hypaque gradient was recovered and resuspended in McCoy's. Additional anti-A and/or - B antisera were added and incubated with mixing at $24^{\circ} \mathrm{C}$ for $3-5 \mathrm{~min}$. The suspension was centrifuged at $1,000 \mathrm{~g}$ at $24^{\circ} \mathrm{C}$ for $2 \mathrm{~s}$ and the supernate recovered and centrifuged at $3,000 \mathrm{~g}$ at $24^{\circ} \mathrm{C}$ for $1 \mathrm{~min}$. The superrate was then discarded and the pellet resuspended in $\mathrm{N}:$ Coy's and centrifuged at $1,000 \mathrm{~g}$ at $24^{\circ} \mathrm{C}$ for $15 \mathrm{~s}$ to remove contaminating light cells. The pelleted cells were then resuspended in TC-199 to the desired concentration. Peripheral blood lymphocytes were prepared as described above for the light cell fraction with heparinized peripheral blood. Cytocentrifuge slides of the fractionated bone marrow were stained with MayGrunwald-Giemsa and differential counts performed.

Mixed lymphocyte culture (MLC). MLC studies were performed by using a one-way semimicro-technique (19). Briefly, responder cells $\left(5 \times 10^{4}\right)$ mixed with an equal number of stimulator cells in $0.1 \mathrm{ml}$ were incubated at $37^{\circ} \mathrm{C}$ for $96 \mathrm{~h}$. Tritiated thymidine $(0.5 \mu \mathrm{Ci}$; sp act $22 \mathrm{Ci} / \mathrm{mmol}$; Schwarz/Mann Div., Becton, Dickinson \& Co., Orangeburg, $\mathrm{N}$.Y.) was added for an additional $16 \mathrm{~h}$ and cultures harvested. The trichloroacetic acid-precipitable $\left[{ }^{3} \mathrm{H}\right]$ thymidine was quantified by counting in a Searle scintillation counter (Amersham/Searle Corp., Arlington Heights, Ill.). Results are expressed as mean \pm SEM counts per minute of triplicate cultures. Stimulation ratios were calculated by dividing the mean counts per minute of stimulated cultures by the mean of autologous control cultures (background). Stimulation indices $\geq 2$ are significant (19). Stimulator cells pretreated with mitomycin are designated by the subscript "M."

Mitogen stimulation. Mitogen stimulation studies were performed under conditions identical to those used for the MLC. Responder cells, $1 \times 10^{5}$ in $0.1 \mathrm{ml}$, were mixed with $0.001 \mathrm{ml}$ of serial twofold dilutions of phytohemagglutininII (PHA-M ; Difco Laboratories, Detroit, Mich.) or 0.01 $\mathrm{ml}$ of a serial dilutions of concanavalin A (ConA; Calbiochem, Los Angeles, Calif.) and incubated for $96 \mathrm{~h}$. Cultures were processed as previously described.

$T$-rosette-forming cells $(T-R F C)$. Spontaneous T-RFC were determined by a modification of the method previously described $(20) .5 \times 10^{5}$ cells $(0.1 \mathrm{ml})$ in Hanks' balanced salt solution (HBSS; Grand Island Biological Co.) were mixed with $0.1 \mathrm{ml}$ of a $5 \%$ suspension of sheep red blood cells (SRBC) in a disposable glass $16 \times 75-\mathrm{mm}$ test tube. Fresh SRBC in Alsevers' solution were obtained weekly (Rosemead Laboratories, Rosemead, Calif.), washed twice before use, and resuspended in HBSS. $25 \mu 1$ of fetal calf serum, previously absorbed with 1 vol of SRBC, was added and the mixture centrifuged at $400 \mathrm{~g}$ at $4^{\circ} \mathrm{C}$ for 5 min. Tubes were incubated at $24^{\circ} \mathrm{C}$ for $90 \mathrm{~min}$, the pellet gently resuspended, and an aliquot removed for counting. T-RFC were determined by phase microscopy; viable cells surrounded by three or more SRBC were scored as rosettes. A minimum of 100 cells was counted and T-RFC reported as a percentage.
B-rosette-forming cells $(B-R F C)$. B-RFC were determined by rosette formation with antibody (A) - and complement (C)-coated SRBC (E)--EAC'. A 5\% solution of SRBC was incubated with anti-sheep-hemolysin A (Grand Island Biological Co.) at one dilution below the hemagglutinating titer, at $37^{\circ} \mathrm{C}$ for $30 \mathrm{~min}$ ( $1 \mathrm{vol} / 1 \mathrm{vol}$ ). The "sensitized" SRBC were washed twice, resuspended in HBSS, and incubated with a $10^{-1}$ dilution of normal mouse serum ( $1 \mathrm{vol} / 1 \mathrm{vol})$ at $37^{\circ} \mathrm{C}$ for $30 \mathrm{~min}$. These $\mathrm{SRBC}$, designated "EAC'," were washed three times and resuspended in HBSS. The cells to be tested $\left(5 \times 10^{5}\right.$ in $0.1 \mathrm{ml}$ ) and $0.1 \mathrm{ml}$ of a $0.5 \%$ suspension of $\mathrm{EAC}^{\prime}$ were incubated on a rotating wheel $(6 \mathrm{rpm})$ at $37^{\circ} \mathrm{C}$ for 60 min. B-RFC were determined microscopically in the same manner as T-RFC. The assay detects cells with a $\mathrm{C}^{\prime} 3$ receptor (21). Controls using unsensitized and sensitized $\mathrm{SRBC}$ did not form rosettes under these conditions.

Immunofluorescence. Immunoglobulin-bearing cells were determined by direct staining with fluorescein-conjugated anti-immunoglobulin $(22) .5 \times 10^{5}$ cells $(0.1 \mathrm{ml})$ were washed twice in phosphate-buffered saline (PBS) and incubated with $0.015 \mathrm{ml}$ of fluorescein-conjugated goat antihuman immunoglobulin (Meloy Laboratories Inc., Springfield, Va.) at $0^{\circ} \mathrm{C}$ for $30 \mathrm{~min}$. Cells were washed three times in cold PBS with $0.02 \% \mathrm{NaN}_{3}$ and immunofluorescent-positive cells were determined by fluorescence microscopy (E. Leitz, Wetzler, Germany).

Marrow cell culture. Colony-forming cells (CFU-C) were assayed by a standard double-layer agar technique (23, 24). McCoy's 5A medium with $15 \%$ fetal calf serum and antibiotics was used throughout. Bone marrow cells were washed in complete medium and viable cell counts performed in a hemocytometer with trypan blue. $2 \times 10^{5}$ marrow cells were plated in $0.3 \%$ agar on feeder layers of $1 \times 10^{8}$ normal peripheral leukocytes immobilized in $0.5 \%$ agar. Duplicate plates were incubated in a humidified environment of $7.5 \% \quad \mathrm{CO}_{2}$ at $37^{\circ} \mathrm{C}$. Colonies composed of 40 or more cells were counted in the upper agar layer at 10 days with a dissecting microscope. Selected colonies were "picked" with a finely drawn pipette, smeared, and stained with Giemsa for morphological examination.

${ }^{51} \mathrm{Cr}$-labcled $R B C$ studies. Radiochromium studies were kindly performed by Dr. William Figueroa. The percent of a bone marrow aliquot which might be contributed by dilution with peripheral blood was determined as follows. $20 \mathrm{ml}$ of sterile heparinized blood was labeled with ${ }^{51} \mathrm{Cr}$ as described (25) and reinjected into the donor. Simultaneous blood and bone marrow were obtained at $180 \mathrm{~min}$ and aliquots assayed for hemoglobin concentration and gamma emission.

\section{RESULTS}

Bone marrow fractionation. Bone marrow was separated into light (fraction I, Fig. 1) and heavy (fraction II, Fig. 2) fractions by density centrifugation. Fraction I was comprised predominantly of lymphocytes; small numbers of immature granulocytes and monocytes were present (Table I). Fraction II contained granulocytes in all stages of differentiation; there was minimal contamination with lymphocytes and monocytes. Small numbers of nucleated RBC's and plasma cells were observed in both fractions.

Cell surface markers. The results of studies of $\mathrm{T}$ and B-cell surface markers are presented in Table II. Peripheral blood contained $2 \times 10^{6}$ lymphocytes per $\mathrm{ml}$, 


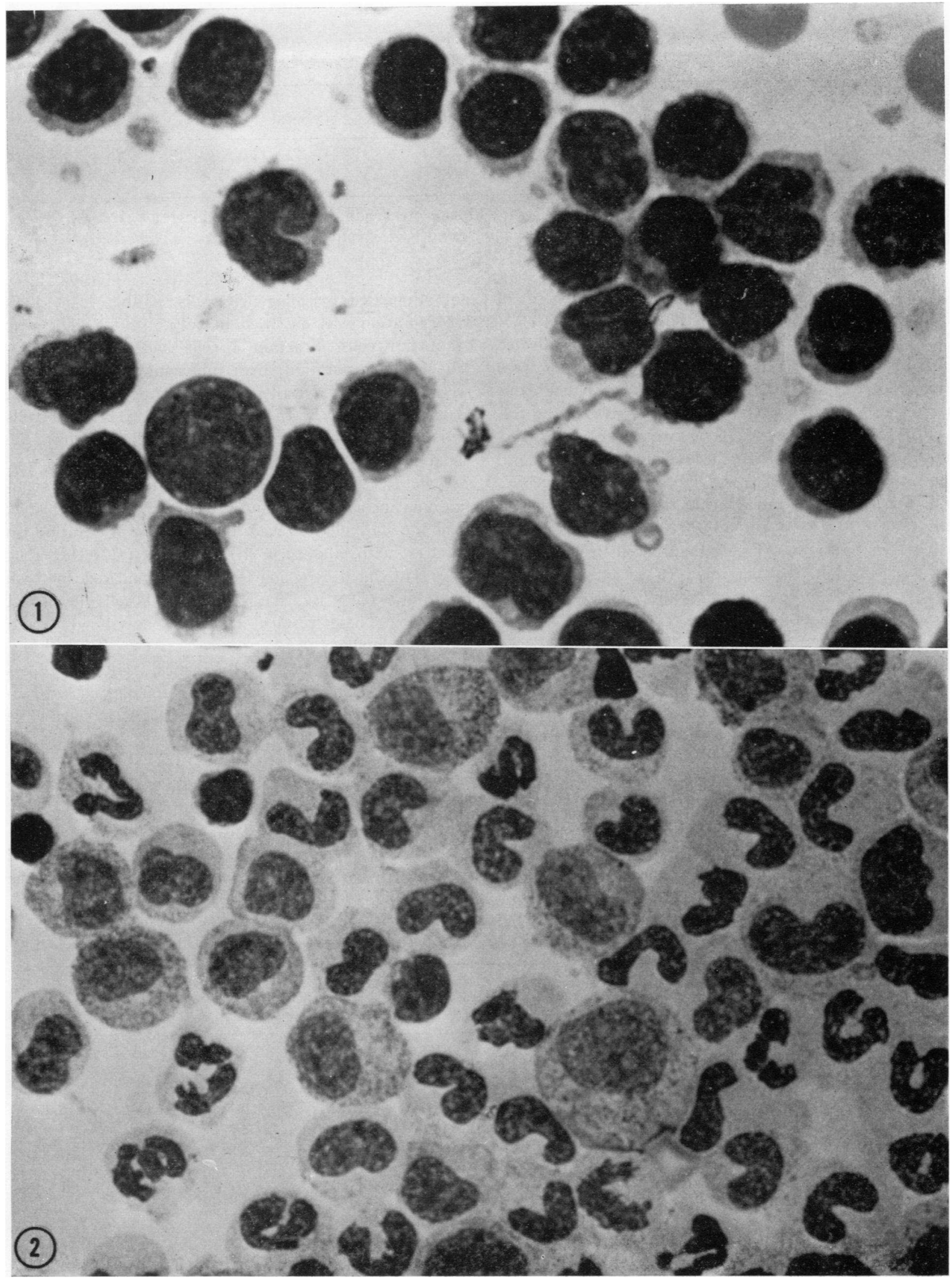

FIGURE 1 Fraction I cells. Light-density bone marrow cells fractionated by buoyant density centrifugation.

FIGURE 2 Fraction II cells. Heavy-density bone marrow cells fractionated by buoyant density centrifugation. 
TABLE I

Differential Counts of Fractionated Bone Marrow

\begin{tabular}{lcccccccc}
\hline & Blast & Pro & Myelo & $\begin{array}{c}\text { Meta to } \\
\text { PMN }\end{array}$ & Mono & NRBC & Lymph & $\begin{array}{c}\text { Plasma } \\
\text { cell }\end{array}$ \\
\hline Fraction I* & 1 & - & 1 & - & 2 & 1 & 94 & 1 \\
Fraction $\mathrm{II}^{*}$ & 1 & 2 & 20 & 65 & 5 & 2 & 5 & - \\
\hline
\end{tabular}

Blast, undifferentiated cell; Pro, promyelocyte; Myelo, myelocyte; Meta, metamyelocyte; PMI, mature granulocyte; Mono, monocyte; NRBC, nucleated RBC; lymph, lymphocyte.

* See Methods.

$70 \%$ of which were $\mathrm{T}$ cells; the total $\mathrm{T}$-cell content of peripheral blood was therefore $1.4 \times 10^{6}$ per $\mathrm{ml}(2 \times$ $\left.10^{8} \times 0.70\right)$. Similar calculations for $\mathrm{B}$ cells indicated $0.3-0.4 \times 10^{6} \mathrm{~B}$ cells per ml. Identical calculations were performed for unfractionated and fractionated bone marrow cells. Examination of Table II reveals the following (a) unfractionated bone marrow contains sixfold more $\mathrm{T}$ cells than can be explained by peripheral blood contamination ( 8.7 vs. $1.4 \times 10^{8}$ per $\mathrm{ml}$ ); (b) similar results were found evaluating bone marrow $\mathrm{B}$ cells (2.0 vs. $0.3 \times 10^{6}$ per $\left.\mathrm{ml}\right)$; (c) there are approximately four times more $\mathrm{T}$ cells than $\mathrm{B}$ cells in bone marrow (7.3 vs. $1.7 \times 10^{6}$ per $\left.\mathrm{ml}\right)$; $(d)$ fractionation results in a $50-55 \%$ cell recovery with no selection for fraction I vs. fraction II cells or $\mathrm{T}$ vs. B cells (45 vs. $55 \%) ;(e)$ fraction I contained cells with T- and B-cell markers; $(f)$ fraction II contained a small number of $\mathrm{T}$ - and B-RFC and a large number of immunofluorescence positive cells. The latter exhibited a speckled staining pattern characteristic of aggregate binding, rather than the diffuse pattern of surface immunoglobulin observed with fraction I cells; $(g) 65-75 \%$ of bone marrow lymphocytes could be classified as $\mathrm{T}$ or B cells by using these markers.

$M L C$. Unfractionated bone marrow cells had a high spontaneous $\left[{ }^{3} \mathrm{H}\right]$ thymidine incorporation and were not stimulated by allogeneic cells (Table III). Less incorporation was observed in cultures with allogeneic stimulator cells. Fraction I cells had a lower spontaneous incorporation than unfractionated cells and were stimulated by allogeneic lymphocytes $\left(B \times D_{m}\right.$, $\mathrm{B} \times \mathrm{E}_{\mathrm{m}}$-Table IV). In most instances, fraction I cells had a lower stimulation index than lymphocytes from the same donor tested against the same stimulator cell $(\mathrm{A} \times$ $\mathrm{D}_{\mathrm{m}}$ vs. $\left.\mathrm{B} \times \mathrm{D}_{\mathrm{m}}\right)$. Fraction II cells had a high spontaneous incorporation and could not be stimulated. Fraction II cells showed decreased incorporation in cultures with allogeneic lymphocytes $\left(C \times D_{m}, D \times\right.$ $\left.E_{m}\right)$. Unrelated lymphocytes were stimulated by both fraction I $\left(D \times B_{m}, E \times B_{m}\right)$ and II cells $\left(D \times C_{m}\right.$, $\left.E \times C_{m}\right)$. These results were reproduced with cells from five donors.

To evaluate responder cell kinetics, MLC were performed with a fourfold number of responder cells. Fraction II cells were not stimulated by allogeneic cells while fraction I cells exhibited an increase in the stimulation index.

Mitogen response. Fractionated marrow cells were tested for response to PHA and ConA (Table V). Fraction I cells were stimulated by both mitogens and fraction II cells were not. Similar results were obtained over a range of mitogen concentrations. Doubling the

TABLE II

Cell Surface Markers in Blood and Bone Marrow

\begin{tabular}{|c|c|c|c|c|c|c|c|c|}
\hline \multirow[b]{2}{*}{ Source } & \multicolumn{2}{|c|}{ Cell concentration } & \multicolumn{2}{|c|}{$\mathrm{T}$ cells } & \multicolumn{4}{|c|}{ B cells } \\
\hline & Lymphoid & Nonlymphoid & $\%$ T-RFC* & Totalt & $\%$ B-RFC* & Totalł & $\% \operatorname{IF}(+) *$ & Totalt \\
\hline & \multicolumn{2}{|c|}{$\times 10^{6} / \mathrm{ml}$} & & $\times 10^{6} / \mathrm{ml}$ & & $\times 10^{6} / \mathrm{ml}$ & & $\times 10^{6} / \mathrm{ml}$ \\
\hline $\begin{array}{c}\text { Peripheral blood } \\
\text { lymphocytes } \$\end{array}$ & 2.0 & 0.1 & 70 & 1.4 & 16 & 0.3 & 20 & 0.4 \\
\hline Bone marrow $\|$ & 11.0 & 18.0 & 30 & 8.7 & 7 & 2.0 & 41 & 12.2 \\
\hline Fraction I 9 & 5.1 & 0.2 & 59 & 3.0 & 16 & 0.8 & 25 & 1.2 \\
\hline Fraction II $\uparrow$ & 0.2 & 9.3 & 10 & 0.9 & 4 & 0.3 & 50 & 4.7 \\
\hline
\end{tabular}

* T-RFC, spontaneous rosettes with $\mathrm{SRBC}$; B-RFC, rosettes with $\mathrm{EAC}^{1}$; IF (+), immunofluorescent positive cells; see Methods.

‡ Total obtained by multiplying cell concentration by the percent marker.

$\S$ Mononuclear cell fraction; see Methods.

|| Unfractionated bone marrow.

T Fraction I and II obtained by density centrifugation; see Methods. 
TABLE III

MLC Reactivity of Bone Marrow*

\begin{tabular}{|c|c|c|c|c|c|c|c|c|}
\hline \multicolumn{3}{|c|}{ Responder cell } & & \multicolumn{5}{|c|}{ Stimulator cellf } \\
\hline Cell & Donor & Typeई & & AM & By & $C_{M}$ & $D_{\mathbf{X}}$ & $\overline{E_{M}}$ \\
\hline \multirow[t]{3}{*}{$\mathrm{A}$} & A. D. & Lymph & Mean & 383 & 796 & 3,147 & 2,486 & 4,019 \\
\hline & & & SEM & 44 & 166 & 285 & 331 & 675 \\
\hline & & & SI & 1.0 & 2.1 & 8.2 & 6.5 & 10.5 \\
\hline \multirow[t]{3}{*}{ B } & A. D. & $\mathrm{BM}$ & Mean & 6,196 & 4,887 & 2,283 & 2,843 & 2,078 \\
\hline & & & SEM & 999 & 307 & 286 & 774 & 350 \\
\hline & & & SI & 1.3 & 1.0 & 0.5 & 0.6 & 0.4 \\
\hline \multirow[t]{3}{*}{$\mathrm{C}$} & R. G. & Lymph & Mean & 4,969 & 3,566 & 1,553 & 1,476 & 4,509 \\
\hline & & & SEM & 456 & 285 & 136 & 111 & 403 \\
\hline & & & SI & 3.2 & 2.3 & 1.0 & 1.0 & 2.9 \\
\hline \multirow[t]{3}{*}{ D } & R. G. & BM & Mean & 3,003 & 4,370 & 6,233 & 5,622 & 3,508 \\
\hline & & & SEM & 298 & 422 & 1,971 & 397 & 445 \\
\hline & & & SI & 0.5 & 0.8 & 1.1 & 1.0 & 0.6 \\
\hline \multirow[t]{3}{*}{$\mathrm{E}$} & $\mathrm{UC} \|$ & Lymph & Mean & 9,236 & 7,828 & 8,403 & 8,208 & 1,538 \\
\hline & & & SEM & 508 & 1,330 & 1,340 & 1,246 & 218 \\
\hline & & & SI & 6.0 & 5.1 & 5.5 & 5.3 & $/ 1.0$ \\
\hline
\end{tabular}

* See Methods for details. Results are expressed as mean \pm SEM counts per minute; $n=3$. SI, stimulation index. $\ddagger$ Mitomycin pretreated.

$\S$ Lymph, peripheral blood lymphocyte; BM, unfractionated bone marrow.

|| UC, unrelated control.

TABLE IV

MLC Reactirity of Fractionated Bone Marrow*

\begin{tabular}{|c|c|c|c|c|c|c|c|c|}
\hline \multicolumn{3}{|c|}{ Responder cell } & & \multicolumn{5}{|c|}{ Stimulator cell } \\
\hline Cell & Donor & Types & & AM & By & $C_{M}$ & Dx & $\overline{E_{M}}$ \\
\hline \multirow[t]{3}{*}{ A } & M. K. & Lymph & Mean & 1,263 & 1,163 & 1,234 & 10,497 & 8,836 \\
\hline & & & SEM & 453 & 190 & 131 & 1,298 & 1,074 \\
\hline & & & SI & 1.0 & 0.9 & 1.0 & 8.3 & 7.0 \\
\hline \multirow[t]{3}{*}{ B } & M. K. & I & Mean & 2,320 & 1,685 & 1,962 & 9,496 & 9,420 \\
\hline & & & SEM & 123 & 49 & 354 & 558 & 1,958 \\
\hline & & & SI & 1.4 & 1.0 & 1.2 & 5.6 & 5.6 \\
\hline \multirow[t]{3}{*}{ C } & M. K. & II & Mean & 11,320 & 10,135 & 11,889 & 4,703 & 4,719 \\
\hline & & & SEM & 1,703 & 1,774 & 453 & 346 & 396 \\
\hline & & & SI & 1.0 & 0.9 & 1.0 & 0.4 & 0.4 \\
\hline \multirow[t]{3}{*}{ D } & UC-1\| & Lymph & Mean & 13,978 & 13,555 & 9,901 & 2,070 & 6,143 \\
\hline & & & SEM & 2,195 & 422 & 101 & 65 & 793 \\
\hline & & & SI & 6.8 & 6.6 & 4.8 & 1.0 & 3.0 \\
\hline \multirow[t]{3}{*}{$\mathrm{E}$} & UC-2 & Lymph & Mean & 9,135 & 9,596 & 6,695 & 7,045 & 1,373 \\
\hline & & & SEM & 638 & 471 & 247 & 1,099 & 8 \\
\hline & & & SI & 6.7 & 7.0 & 4.9 & 5.1 & 1.0 \\
\hline
\end{tabular}

* See Methods for details. Results expressed as mean $\pm \mathrm{SEM}$ counts per minute $\pm \mathrm{SEM} ; n=3$. SI, stimulation index. $\ddagger$ Mitomycin pretreated.

\$ Lymph, peripheral blood lymphocyte; I, light-density bone marrow cells; II, heavy density bone marrow cells. See Methods.

|l LC, unrelated control. 
TABLE V

Mitogenic Response of Bone Marrow to PH.1 and Con. ${ }^{*}$

\begin{tabular}{lclccc}
\hline \multicolumn{2}{c}{ Responder cell } & & & & \\
\hline Donor & Type & & Controlł & PHA & $\begin{array}{c}\text { Mitogen } \\
\text { ConA\& }\end{array}$ \\
\hline M. K. K. & Lymph & Mean & 1,840 & 64,728 & 60,792 \\
& & SEM & 440 & 153 & 3,596 \\
& & SI & 1.0 & 35.2 & 33.0 \\
M. K. & I & Mean & 3,634 & 47,468 & 51,772 \\
& & SEM & 471 & 794 & 5,453 \\
& & SI & 1.0 & 13.1 & 14.2 \\
M. K. & II & Mean & 19,701 & 21,119 & 23,377 \\
& & SEM & 4,886 & 1,645 & 3,886 \\
& & SI & 1.0 & 1.1 & 1.2 \\
\hline
\end{tabular}

* See Methods for details. Results are expressed as mean \pm SEM counts per minute; $n=3$. SI, stimulation index.

$\ddagger$ Lymph, peripheral blood lymphocytes; I and II, light- and heavy-density bone marrow cells.

$\S \mathrm{PHA}$, phytohemagglutinin $\mathrm{M}, 1: 4$; Con. $\mathrm{A}$, Concanavalin A, $7.8 \mu \mathrm{g}$.

number of responder cells resulted in the same pattern of response to PHA and allogeneic cell stimulation. Peripheral blood lymphocytes and fraction I cells were compared for proliferative response over a range of PHA and ConA concentrations (Fig. 3). Approximately similar curves were observed but peripheral blood lymphocytes consistently proliferated to a greater degree than fraction I cells. Both populations tested contained an equivalent percentage of $\mathrm{T}$ cells $(70 \mathrm{vs} .65 \%)$.

Colony-forming capacity. Unfractionated bone marrow contained between 28 and $140 \mathrm{CFC}^{-} \mathrm{C}$ per $2 \times 10^{5}$ marrow cells (Table VI). Fraction I cells were en-

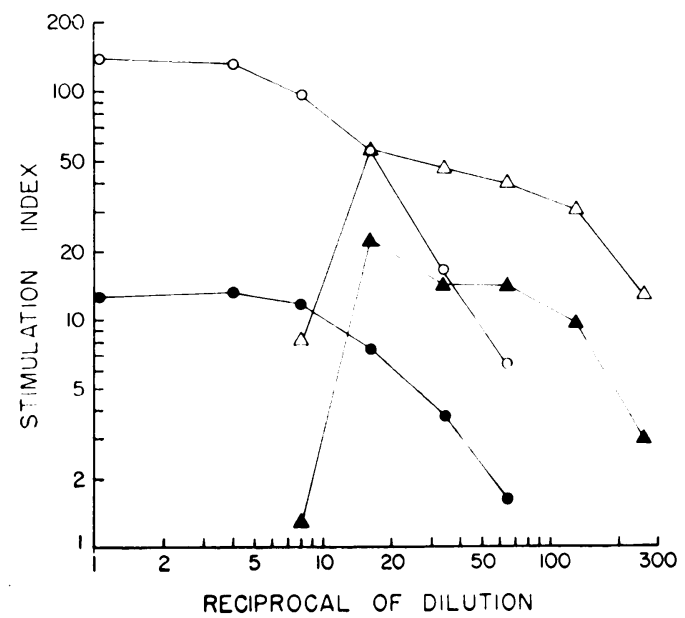

FigUre 3 Response of peripheral blood (open symbols) and fraction I cells (closed symbols) to T-cell mitogens PHA $(O)$ and ConA $(\triangle)$.
TABLE VI

Colony Forming Acticity $\left(C F L^{-}-C\right)$ of Bone Marrow

\begin{tabular}{ccc}
\hline Experiment & Cell fraction* & CFC-C $¥$ \\
\hline & & $\begin{array}{c}\text { per } 2 \times 10^{5} \\
\text { cells plated }\end{array}$ \\
1 & BM & 140 \\
& I & 410 \\
& II & 50 \\
2 & B.I & 35 \\
I & 190 \\
& II & 5 \\
3 & B.M & 28 \\
& I & 195 \\
& II & 3 \\
& I & 95 \\
4 & II & 11
\end{tabular}

* B.I, unfractionated bone marrow; I and II, light- and heavy-density fractions of bone marrow, respectively.

$\ddagger$ Colony forming cells in culture per $2 \times 10^{5}$ cells plated; see Methods. Mean of duplicate cultures.

riched three- to sixfold for $\mathrm{CFL}^{-} \mathrm{C}$ while fraction II cells were markedly depleted. Morphologic examination of colonies from the three populations failed to reveal significant differences.

${ }^{51}$ Cr-labcled $R B C$ studics. Peripheral blood samples had a hemoglobin concentration of $13.6 \mathrm{~g} / 100 \mathrm{ml}$ while in bone marrow it was $14.2 \mathrm{~g} / 100 \mathrm{ml}$. Gamma emissions of a $1-\mathrm{ml}$ aliquot of blood and bone marrow were 327 and $288 \mathrm{cpm}$, respectively. These studies suggest that $88 \%$ of bone marrow volume is composed of peripheral blood. The remaining $12 \%$ is composed of bone marrow cells $(\leq 3 \%)$ and marrow "fluid" not in 180-min equilibrium with the peripheral blood.

\section{DISCUSSION}

Human bone marrow contains cells with characteristics of $\mathrm{T}$ lymphocytes. These cells demonstrated rosette formation with sheep erythrocytes, reactivity in MLC, and responsiveness to $\mathrm{T}$-cell mitogens (PHA and ConA).

Bone marrow can be fractionated on the basis of cell density into MLC-responsive and nonresponsive subpopulations. The responsive population (fraction I) contains cells with morphologic, functional, and cell surface marker characteristics of lymphocytes. The fraction also contains cells with the ability to form granulocytes and monocyte-macrophage colonies in semisolid gel (CFU-C). The MLC-nonresponsive population (fraction II) contains predominantly immature and mature granulocytes; very small numbers of T-RFC are present. This fraction is depleted of cells with CFU-C 
activity, is unresponsive to mitogenic stimulation, and is able to stimulate allogeneic lymphocytes strongly. Fraction II cells exhibit a high spontaneous DNA synthetic level that was reduced in the presence of allogeneic lymphocytes. The mechanism underlying this phenomenon is unclear.

The present study differs from previous reports (4, $5,14)$ in several regards: (a) We demonstrated T-RFC in bone marrow. The method of rosette testing differed from other studies. (b) We were unable to demonstrate MLC reactivity in unfractionated bone marrow. The MLC reactivity of unfractionated bone marow reported by some authors (14) was low with stimulation indices $<2$. (c) We found a substantial DNA synthetic response to PHA, using a different source and concentration of the mitogen. Our findings are similar to those reported in murine systems. Claman (6) demonstrated a $\mathrm{PHA}$ and a ConA response in murine bone marrow and El-Arini and Osoba (7) have demonstrated $\mathrm{T}$ cells and $\mathrm{T}$-cell progenitors in light-density fractions of $\mathrm{mu}$ rine bone marrow. These investigators were able to show MLC reactivity and graft versus host disease (11) with marrow lymphocytes. Burkart and Meuwissen (13) have demonstrated $\mathrm{PHA}$ - and pokeweed mitogen-responsive cells in primate bone marrow.

It is important to exclude contamination of bone marrow samples with peripheral blood as the sole source of $\mathrm{T}$ cells. Several arguments militate against this possibility. All marrow samples were exactly $1-\mathrm{ml}$ aspirates and were carefully collected. Dicke and Lowenberg showed no increase in PHA responsiveness of marrow aliquots in a range of $0.3-3 \mathrm{ml}(26)$. While the percent of $\mathrm{T}$ cells ( $\mathrm{T}-\mathrm{RFC}$ ) is comparable to peripheral blood $\mathrm{T}$-lymphocyte levels, the response to mitogens and alloantigens was significantly different. Finally, the absolute number of $\mathrm{T}$ cells in bone marrow is too high to be accounted for by contamination with peripheral blood $\mathrm{T}$ cells. This data is additionally supported by the observations obtained with ${ }^{51} \mathrm{Cr}$-labeled erythrocytes.

It is not clear whether bone marrow $T$ cells are identical to peripheral blood $\mathrm{T}$ cells. Bone marrow $\mathrm{T}$-cell progenitors in mice appear to have decreased or absent $\theta$-antigen on their surface and have different response curves to PHA and ConA $(27,28)$. The situation in man may be comparable. The data on $\theta$-antigen has not been resolved but differences in responsiveness to PHA, ConA, and alloantigens were observed in this study.

The presence of $T$ cells in human marrow may relate to the high incidence of graft versus host disease in bone marrow transplant recipients (29). As MLCreactive cells are hypothesized to be precursors of cells responsible for mediating graft versus host disease, fractionation of bone marrow into MLC-reactive and nonreactive populations has potentially important implica- tions. Cells with colony-forming activity segregated with MLC-reactive cells. This is not unexpected in view of the reported lymphocytoid morphology and density of the colony-forming cell $(16,30)$. There is no assay for the pluripotent stem cell in man. Nonetheless, data from animal work indicate that pluripotent stem cells, committed granulopoietic precursors (CFU-C), and bone marrow $\mathrm{T}$ cells and $\mathrm{T}$-cell progenitors are present in light-density fractions. Even if these cells could be separated completely from bone marrow, the clinical value of doing so must be questioned. For example, if $\mathrm{T}$ cells were selectively removed from transplanted bone marrow, functional $T$ cells could arise in the host from precursor lymphocytes or from the pluripotent stem cell. Our data suggest that the complete spectrum of lymphoid cell differentiation is manifest in human bone marrow.

Note added in proof: Since the preparation of the manuscript, A. S. Fauci has published data confirming several of the aspects presented in this paper (1975. Human bone marrow lymphocytes. I. Distribution of lymphocyte subpopulations in the bone marrow of normal individuals. J. Clin. Inc'est. 56: 98-110).

\section{ACKNOWLEDGMENTS}

The authors wish to acknowledge the expert technical assistance of Ms. Nancy Rupard, Mr. Victor Chan, Mr. Douglas Rakich, and Ms. Ann Sullivan.

This work was supported by grant CA 12800 , contract NOICP 43211 from the National Cancer Institute, National Institute of Health, Bethesda, Md., and grant RR 00865 from the U. S. Public Health Service.

\section{REFERENCES}

1. Cooper, M. D., R. D. A. Peterson, M. A. South, and R. A. Good. 1966. The functions of the thymus system and the bursa system in the chicken. J. Exp. Med. 123: 75-102.

2. Alm, G. V., and R. D. A. Peterson. 1969. Antibody and immunoglobulin production at the cellular level in bursectomized-irradiated chickens. J. Exp. Med. 129: 1247-1259 + plates 11-14.

3. Warner, N. L., J. W. Uhr, G. J. Thorbecke, and Z. Ovary. 1969. Immunoglobulins, antibodies and the bursa of fabricius; induction of agammaglobulinemia and the loss of all antibody-forming capacity by hormonal bursectomy. J. Immunol. 103 : 1317-1330.

4. Abdou, N. I., and N. L. Abdou. 1972. Bone marrow, the bursa equivalent in man? Science (Wash. D. C.). 175 : 446-448.

5. Pegrum, G. D., D. Ready, and E. Thompson. 1968. I. The in iitro effect of phytohaemagglutinin of separated human bone marrow cells. Br. J. Haematol. 15: 377380 .

6. Claman, H. N. 1974. Bone marrow T cells. Response to the $T$ cell mitogens, phytohemagglutinin and concanavalin A. J. Immunol. 112: 960-964.

7. El-Arini, M. O., and D. Osoba. 1973. Differentiation of thymus-derived cells from precursors in mouse bone marrow. J. Exp. Med. 137: 821-837. 
8. Moorhead, J. W., and H. N. Claman. 1972. Thymusderived lymphocytes and hydrocortisone: identification of subsets of theta-bearing cells and redistribution to bone marrow. Cell. Immunol. 5: 74-86.

9. Andersson, J., O. Sjöberg, and G. Möller. 1972. Mitogens as probes for immunocyte activation and cellular cooperation. Transplant. Rev. 11: 131-177.

10. Janossy, G., and M. F. Greaves. 1971. Lymphocyte activation. I. Response of $\mathrm{T}$ and $\mathrm{B}$ lymphocytes to phytomitogens. Clin. Exp. Immunol. 9: 483-498.

11. Cohen, J. J., and N. H. Claman. 1971. Hydrocortisone resistance of activated initiator cells in graft versus host reaction. Nature (Lond.). 229: 274-275.

12. Park, B. H., W. D. Biggar, and R. A. Good. 1972. Paucity of thymus-dependent cells in human bone marrow. Transplantation (Baltimore). 14: 284-286.

13. Burkart, P. T., and H. J. Meuweissen. 1973. Immunocompetent lymphocytes in human and primate marrow. Transplantation (Baltimore). 16: 372-374.

14. Geha, R. S., J. G. Gatien, R. Parkman, J. D. Crain, F. S. Rosen, and E. Merler. 1974. Discontinuous density gradient analysis of human bone marrow: presence of alloantigen-responsive, PHA-unresponsive cells in normal bone marrow; absence of $B$ lymphocytes in the bone marrow of patients with $\mathrm{X}$-linked agammaglobulinemia. Clin. Immunol. Immunopathol. 2: 404-415.

15. Hiewisch, H., H. Vogel, and G. Matioli. 1967. Concentration, quantitation, and identification of hematopoetic stem cells. Proc. Natl. Acad. Sci. U. S. A. 58: 22612267.

16. Zucker-Franklin, D., G. Grusky, and P. L'Esperance. 1974. Granulocyte colonies derived from lymphocyte fractions of normal peripheral blood. Proc. Natl. Acad. Sci. U. S. A. $71:$ 2711-2714.

17. van Bekkum, D. W., M. J. van Noord, B. Maat, and K. A. Dicke. 1971. Attempts at identification of hematopoietic stem cell in mouse. Blood 38: 547-558.

18. Böyum, A. 1968. Isolation of mononuclear cells and granulocytes from human blood. Isolation of mononuclear cells by one centrifugation, and of granulocytes by combining centrifugation and sedimentation at $1 \mathrm{~g}$. Shand. J. Clin. Lab. Inv'est. Suppl. 97: 77-89.

19. Sengar, D. P. S., and P. I. Terasaki. 1971. A semi- micro mixed leukocyte culture test. Transplantation (Baltimore). 11: 260-267.

20. Wybran, J., S. Chantler, and H. H. Fudenberg. 1973. Isolation of normal $\mathrm{T}$ cells in chronic lymphocytic leukaemia. Lancet. 1 : 126-129.

21. Aiuti, F., L. Fontana, and R. A. Gatti. 1973. Membrane-bound immunoglobulin (Ig) and in vitro production of $\mathrm{Ig}$ by lymphoid cells from patients with primary immunodeficiencies. Scand. J. Immunol. 2: 9-16.

22. Opelz, G., M. Kuichi, and M. Takasuki. 1975. Reactivity of lymphocyte subpopulations in human mixed lymphocyte culture. J. Immunogenet. 2: 1-7.

23. Golde, D. W., and M. J. Cline. 1972. Identification of the colony-stimulating cell in human peripheral blood. J. Clin. Ini'est. 51: 2981-2983.

24. Pike, B. L., and W. A. Robinson. 1970. Human bone marrow growth in agar-gel. J. Cell. Physiol. 76: 77-84.

25. International Committee for Standardization in Hematology. 1971. Recommended methods for radioisotope red cell survival studies. Blood. 38: 378-386.

26. Dicke, K. A., and B. Lowenberg. 1974. Elimination of lymphocytes from human marrow suspensions: gradient versus small marrow aspirates. Presented at the Third Annual Meeting of the International Society for Experimental Hematology, 31 March 1974, Houston, Texas.

27. Stobo, J. D., and W. E. Paul. 1972. Functional heterogenieity of murine lymphoid cells. II. Acquisition of mitogen responsiveness and of $\theta$ antigen during the ontogony of thymocytes and "T" lymphocytes. Cell. Immunol. 4 : 367-380.

28. Raff, M. C. 1971. Surface antigenic markers for distinguishing $\mathrm{T}$ and $\mathrm{B}$ lymphocytes in mice. Transplant. Rev. 6: 52-80.

29. Thomas, E. D., R. Storb, R. A. Clift, A. Fefer, F. L. Johnson, P. E. Neiman, K. G. Lerner, H. Glucksberg, and C. D. Buckner. 1975. Bone-marrow transplantation. N. Engl. J. Med. 292: 832-843, 895-902.

30. Dicke, K. A., M. J. van Noord, B. Maat, U. W. Schaefer, and D. W. van Bekkum. 1973. Identification of cells in primate bone marrow resembling the hematopoetic stem cell in the mouse. Blood. 42: 195-208. 